\title{
The Characteristics of Buddhist Communities in Violent Situations in the Lower South of Thailand: A Short Case Study
}

\author{
Thongphon Promsaka Na Sakolnakorn ${ }^{1} \&$ Apichart Chandaeng ${ }^{1}$ \\ ${ }^{1}$ Institute for Peace Studies, Prince of Songkla University, Thailand \\ Correspondence: Thongphon Promsaka Na Sakolnakorn, Institute for Peace Studies, Prince of Songkla \\ University, Hat Yai, Songkhla 90110, Thailand. E-mail: thongphon.p@psu.ac.th
}

Received: April 18, 2014 Accepted: May 5, 2014 Online Published: June 25, 2014

doi:10.5539/ass.v10n13p184 URL: http://dx.doi.org/10.5539/ass.v10n13p184

\begin{abstract}
The objective of this study was to observe the characteristics of Buddhist communities in violent situations. We conducted in-depth interviews and a fieldwork survey, and analyzed the data using descriptive analysis. Buddhists represent less than 10 percent of the population in the lower south of Thailand, and killings, murders, car bombings, and violent situations still occur in Pattani, Yala, and Narathiwat provinces. The goal of terrorists there is to reduce the number of Buddhists and drive Buddhists out of the region. From the study, we present four types of Buddhist communities that remain alive in violent situations: Buddhist communities surrounded by Muslim communities, Buddhist households in Muslim communities, large Buddhist communities, and urban Buddhist communities. We conclude that, in the near future, Buddhist communities may be lost in the lower south of Thailand, and peace is the major hope for people of all religions in the lower south of Thailand.
\end{abstract}

Keywords: Buddhist communities, characteristics, lower south of Thailand

\section{Introduction}

Since the 2004 violence in three provinces (Pattani, Yala, and Narathiwat) in the lower south of Thailand, the trust between Buddhists and Muslims has declined. They have had little contact because the violent situation has made them afraid to have contact between the religions (Sakolnakorn, 2013). The Buddhists are a minority community in the lower south of Thailand, represented by approximately 380,000 Buddhists, or 20 percent of the 1.9 million people in the region (Deep South Watch, 2013). Murders, car bombings, shootings, and assassinations still happen every day in the lower south of Thailand, and many bombings occur in business areas (Sakolnakorn \& Tepsing, 2013). Reports on violence in Pattani, Yala, and Narathiwat and some districts in Songkhla province appear in both the local and international media every day. Violent incidents, which include bomb attacks on and daily killings of state officials and local villagers, have caused concern among people outside these trouble-plagued provinces who are now waiting for the unrest to come to an end. However, many people feel there has already been too much coverage of the violence and have become apathetic, while some others are enraged about the situation (Ratjaroenkhajorn, 2006).

Terrorism in the three southern border provinces is not decreasing. The events are becoming more violent, and the consequence is many deaths and injuries, as well as a great impact on the economy in the area. The government has contributed a large amount of its budget and armed forces toward making peace. The violent situation in the lower south of Thailand stems from many political, economic, social, and religious factors, such as underdevelopment and poverty, the influence of religious ideology, the desire for Pattani State, organized crime, human rights violations, and discrimination. These are structural, historical, and individual factors, but their specific, major causes are the actions of groups including separatists, illegal businessmen, politicians, and local elites, as well as malpractice by public officers and lack of acceptance of local identity (Nakata, 2010).

On March 31, 2014, 11 people were killed, and about 100 more were injured by seven large bombs in central Yala province. The bombers were almost certainly Muslims from shadowy groups, including the Pattani-Malay National Revolutionary Front Co-ordinate (known by its Malay initials, BRN-C). Though Thailand is predominantly Buddhist, ethnic Malays form a Muslim majority in the south (The Economist, 2014). This area is the business area of Chinese Buddhists, who are an influential economic group in Yala province. On February 28, 2013, in Yala province, a separatist militant was killed in a clash with soldiers from the 12th Special Task Force. As they were approaching the targeted house, three armed men ran out and opened fire at the soldiers, who fired 
back. There was a brief gunfight as they fled (Bangkok Post, 2013). On January 2, 2010, three soldiers and three civilians were injured by roadside bombs in Yala (The nation, 2010).

Since 2004, more than 30 percent of Buddhists have migrated to other regions; $40 \%$ of the remaining Buddhists were killed and 60\% received injuries (Isra News Agencies, 2011). Before 2004, more than 100 Buddhist families lived in To Deng subdistrict, but now only one elderly Buddhist family remains in To Deng subdistrict, Su-ngai Padi district, and Narathiwat province (Thai PBS News, 2013). Buddhists are a target for murder; thus, the violent situation is making Buddhist people move to other regions and the next generation is not coming back to work or live in the lower south of Thailand (Sakolnakorn, Sungkharat,, \& Tepsing, 2013). However, many Buddhists in the community are still alive, and they do not want to move because they think of this land as their motherland and were born in this area. In this paper, we will present the characteristics of Buddhist communities in the violent situation.

\section{Objectives}

To study the characteristics of Buddhist communities in violent situations

\section{Methodology}

The location of this study is in the Pattani, Yala, and Narathiwat provinces in the lower south of Thailand. In this study, we did in-depth interviews with 3 heads of villages, 6 assistant heads of villages, and 1 senior colonel of the Pattani Special Task Force Army. We also conducted a fieldwork survey, with the researchers visiting the Buddhist communities in Pattani, Yala, and Narathiwat between January and March 2014. In addition, we analyzed the data using content analysis and descriptive analysis.

\section{Literature Review}

In this subsection, researchers found only a few literature reviews related to Buddhists in the lower south of Thailand, because after the 2004 violence in the lower south of Thailand, most researchers focused on Muslim studies, and few studies or articles were published in English. However, researchers have tried to review some articles related to Buddhists, such as the study of Narongraksakhet, et al. (2006), which found that the real needs of people in the southern border provinces were constituted of four underlying dimensions: participation, cultural diversity, justice and equity, and local identity. For example, Muslim government officers requested to wear their Muslim clothing during their working hours and for Buddhist people to agree for them to wear Muslim clothing; however, Buddhist people wanted the government to understand plural identities and to use participation from every religion and nationality, and all stakeholders, to set up the right policy for administration.

Yongyuan and Padungpong (2010) used art activities to promote respect for cultural diversity among elementary school students in Pattani province, and found that the students' respect for cultural diversity after multicultural art activities in a Muslim classroom was higher than those who had traditional art activities in a Muslim classroom, and respect for cultural diversity among the students from the Muslim classroom treated with multicultural art activities was higher than those from a Buddhist-Muslim classroom treated with the same multicultural arts activities. This study shows that Muslim youth will be more comfortable if they only study with Muslim students because, in mixed classrooms (with Buddhists, Chinese, and Muslims), Muslim students will have many problems, such as in communication skill (Muslims in the lower south of Thailand speak the Malay), and then Muslims will not want to learn about and will criticize Thai or Chinese art because they feel prouder about their Muslim arts.

However, Yongyuan, Day-ma, and Hiransai (2010) found that teachers in the three southern border provinces who differed in sex, religion, education, school department, and hometowns had significant statistical differences in their respect for cultural diversity and cultural understanding with respect to ethnic issues, languages, traditions, and lifestyles; their overall cultural understanding was positively related with their respect for cultural diversity. In addition, teachers who came from other regions respected cultural diversity more than local Muslim teachers.

As stated in the literature reviews above, researchers found that, after 2001, cultural diversity in the lower south of Thailand decreased, due to the real phenomena of many Buddhist temples being deserted, as there were no monks anymore, and many houses of Buddhists around Buddhist temples also being deserted because the violence situation forced them to move to safer areas. The risk in the lower south of Thailand for Buddhists is seen on the news; for example, GlobalPost (2012) stated that Thailand's three southernmost provinces of Yala, Pattani and Narathiwat, which have a predominantly Muslim population, have been hit by bomb and gun attacks since a separatist campaign was reignited in 2004. In addition, on March 10, 2012, eleven people were killed and 
more than one hundred injured in three bomb attacks in Yala province; Muslim insurgents were suspected to be behind the deadly attacks, which happened before lunch time.

Buddhists are the most common shooting and bombing targets; they happen weekly, and sometimes, bombing and shootings happen every day, including at government agencies involved with the Thai government, such as police stations, soldier barracks, the village head's office, and hospital offices. This situation has led Buddhists to move out, and Buddhists in other regions are afraid to work in the lower south of Thailand. In addition, most researchers have focused on the Muslim population, but only a few researchers have focused on Buddhists. This has led to the government setting up many policies supported by Muslims while forgetting Buddhists, which has made it difficult for Buddhists to stay alive in some areas, and the number of Buddhists has declined. Therefore, it is very important to study the Buddhist community in order to gain more knowledge about how they stay alive, how they adjust, and the characteristics of the Buddhist community. We hope that this paper will give some knowledge to government agencies involved in policy to rethink government policies for the lower south of Thailand.

\section{Results}

In this study, we present four types of Buddhist communities in the lower south of Thailand-Buddhist communities surrounded by Muslim communities, Buddhist households in Muslim communities, large Buddhist communities, and urban Buddhist communities:

\subsection{Buddhist Communities Surrounded by Muslim Communities}

The first case study is in a rural area of Pattani province. It has 295 Buddhist households with more than 500 villagers. This community is 100 percent Buddhist, but the surrounding communities are Muslim communities, as shown in Figure 1.

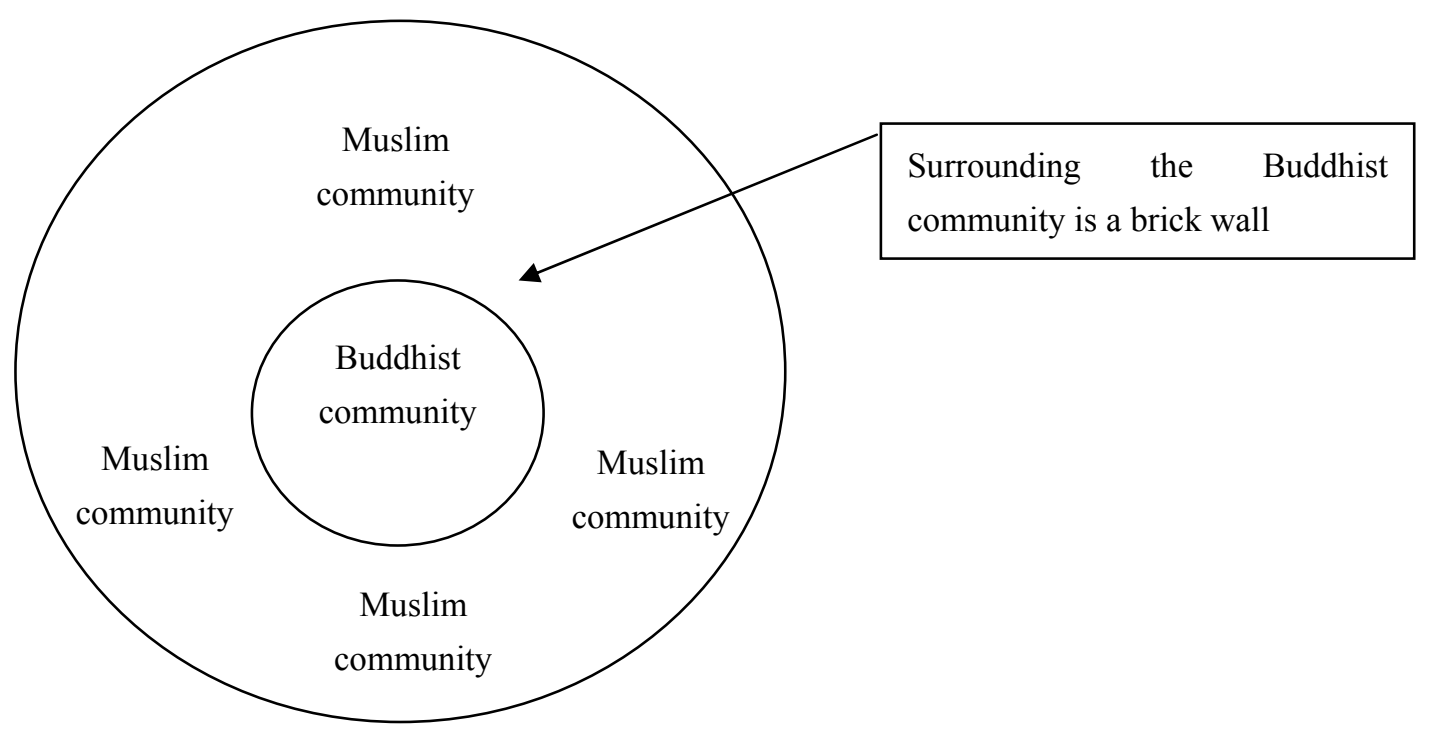

Figure 1. A Buddhist community surrounded by Muslim communities

The community shown in Figure 1 has two gates that are used for transportation into the community; the first is a gated entry to the highway, while the second is a gated entry to the Muslim community. Few Muslims use this way through the Buddhist community to enter their Muslim community, and at the second gate, entry to the Muslim community closes between 6 p.m. and 6 a.m. While the researchers were visiting this Buddhist community, a Buddhist was killed close to the second gate in the Muslim community, and a criminal stole his truck. For safety reasons, the second gate is closed, while the first gate is open 24 hours. The Buddhists also have a security guard at the first gate at night, and security guards patrol the community 24 hours a day. In addition, criminal activity does not happen in the community because it is a very safe zone, but it happens when Buddhists go outside the community, such as to go to work and do their business. 


\subsection{Buddhist Households in Muslim Communities}

The second case study is in a rural area of Narathiwat province. This community is 80 percent Muslim and 20 percent Buddhist (50 households), with approximately 80 Buddhist persons. The Buddhists remain in this community because they were born here, but they all send their sons and daughters to study and live outside Pattani, Yala, and Narathiwat provinces. This village is only interested in having the Buddhist residents of the community come in and out of the community. Buddhists from other communities will not come to visit or start businesses; they are afraid of murder or violence because this community is far away from the highway, approximately 7 kilometers away, and the route to the Buddhist households is surrounded by Muslim communities. The characteristics of this community are shown in Figure 2.

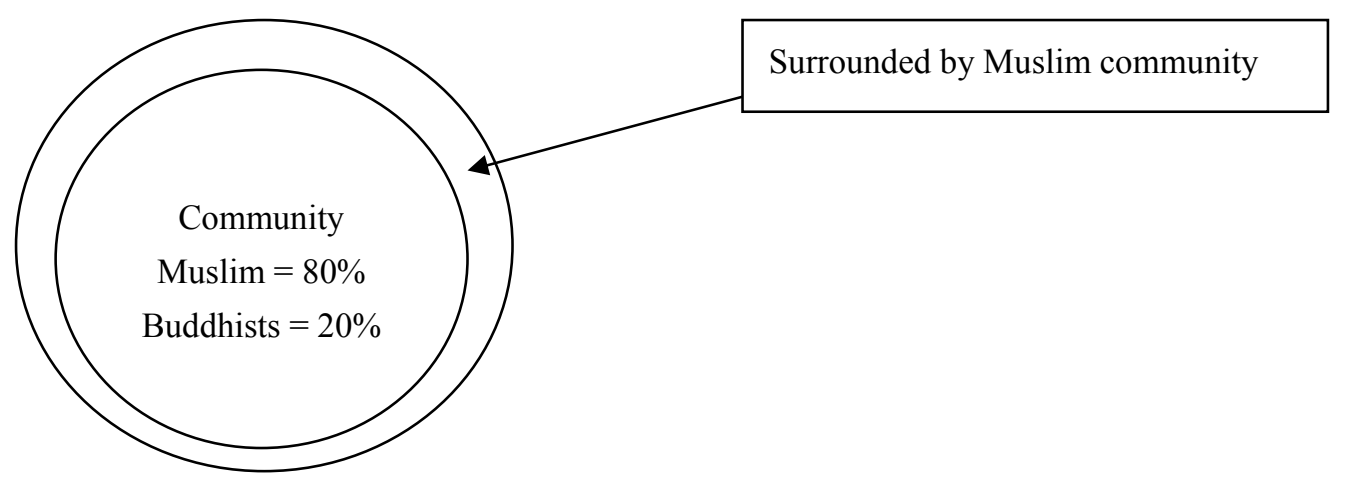

Figure 2. Buddhist households in a Muslim community

For the study, the researchers could not visit this community because the assistant head of the village, a Buddhist, suggested that the researchers should not go into the community. Instead, she came to meet the researcher at a Thai food shop in a Buddhist community area outside her community. From the data acquired from the assistant head of the village, she reported that the head of the village is Muslim and has only one Buddhist as an assistant. Before this Muslim head of the village, the head of the village was a Buddhist. However, the Buddhist ex-head of the village was afraid of the violent situation and was frightened by agitators, so he resigned from his position as head of the village and moved to another area. In addition, Buddhists in this community stay alive because they do not discuss anything involving Muslims when they get back to their community, they do not discuss illegal businesses in the community, and they do not dispute with or contradict their Muslim neighbors. It is not dangerous for them in the community, but they are scared when they go out to work or do business, so they feel safe when they stay in the community because they have an army camp at a Buddhist temple in the community.

\subsection{A Large Buddhist Community}

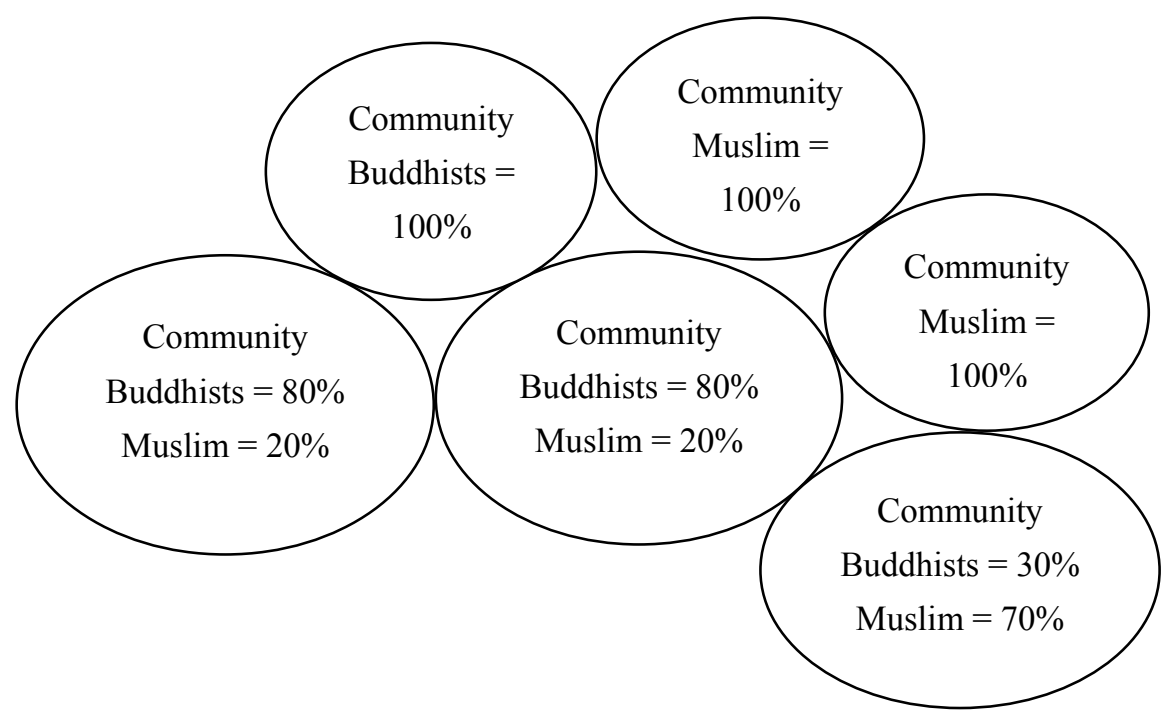

Figure 3. A large Buddhist community 
Large Buddhist communities can be found in Tak Bai, Sungai Kolok, Waeng, and Sukirin districts in Narathiwat province. In this case study, the researchers present the Buddhist communities in the rural Waeng district; their characteristics are shown in Figure 3.

The Buddhist community that the researchers visited is 80 percent Buddhist and 20 percent Muslim. The head of the village is Buddhist, with six Buddhist assistants and three Muslim assistants. In this village, Buddhists and Muslims have lived together by collaborating. In addition, the Buddhist head of the village and Buddhist assistant head of the village suggested in interviews that, if a community has more Buddhists than Muslims, the Buddhists will not have problems and the Muslims will be fine. However, if the number of Buddhists is lower than the number of Muslims, the Buddhists will face many obstacles in life. In addition, this community sets up a security guard team at night, especially in the gateway to the Muslim community, because the Muslim community close to this community is a "red zone," which is an area that has been most affected by armed violence and in which the government feels terrorist organizations have the most influence.

\subsection{Urban Buddhist Communities}

The urban Buddhist community is in a downtown area. It mostly comprises Chinese Buddhists who came and started businesses long ago after migrating from mainland China, Malaysia (after the crisis in 1969), and from other regions of Thailand. In addition, Thai Buddhists also have a long history of settling down in the lower south of Thailand. The urban Buddhist community is a safety zone because it has many police and soldier security checkpoints; however, shootings, murders, and car bombings still happen. This violent situation means that Buddhists spend their lives in fear, and they choose to send their young family members to study outside the danger zone. Some families send their kids to study in Bangkok or Songkhla for their safety, but they still want to stay in the violent area for many reasons. One reason is that it is their homeland. The characteristics of the urban Buddhist community are shown in Figure 4.

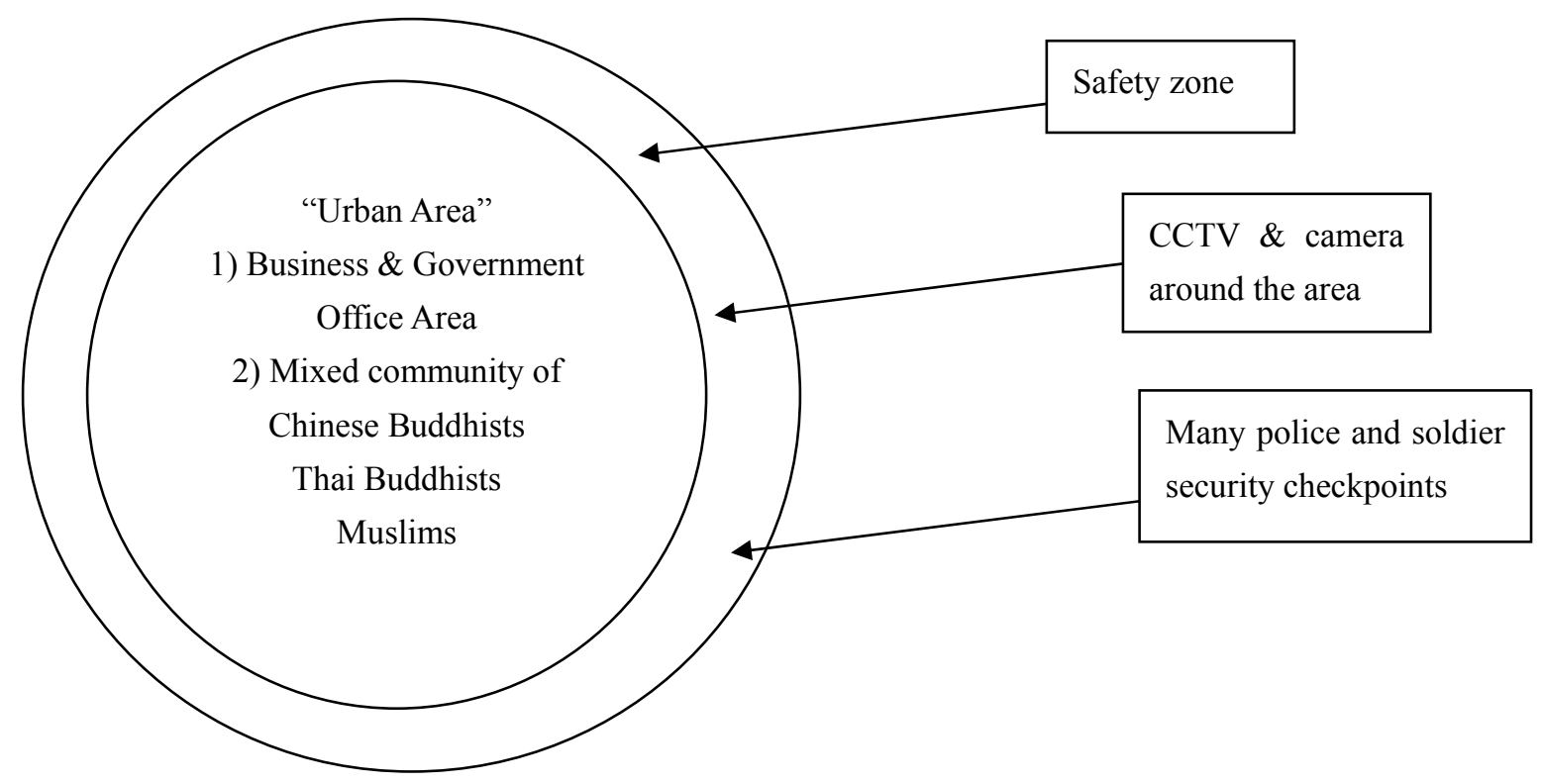

Figure 4. An urban Buddhist community

\section{Conclusion}

Buddhist communities in the lower south of Thailand still face many problems due to the violent situation. To protect themselves from criminal activity and violence, Buddhist volunteers participate in rifle-firing exercises organized by the Royal Thai Army to prepare Buddhist villagers to fend off attacks by Islamic separatist insurgents (Winn, 2012). In this study, we present four types of Buddhist communities: 1) Buddhist communities surrounded by Muslim communities, 2) Buddhist households in Muslim communities, 3) large Buddhist communities, and 4) urban Buddhist communities. More than 80 percent of Buddhists in the lower south of Thailand have weapons, such as pistols and shotguns, and taking care of themselves and protecting their community are the only choice they have. The Royal Thai Military is the hope and light for Buddhist 
communities. Nevertheless, a major problem for Buddhist communities is that younger people do not come back to stay and work in their families' homelands. This is related to the decline of the Buddhist population; they may all be lost in the near future if the current generation all dies. How should the Buddhist communities be maintained? This is hard to answer, but without crime, peace is the big hope of all the people and religions in the lower south of Thailand.

\section{Future Research}

The suggestion for future research is to study the management of Buddhist communities in violent situations.

\section{Limitation of This Study}

It was difficult to access the data for this study. Any time the researchers visited an area for fieldwork, it was dangerous because they could become targets for terrorists, as the areas in question were dangerous. In addition, for safety reasons, we cannot disclose the informants and the specific locations of the fieldwork study.

\section{Acknowledgements}

This research study is part of a research project titled "Self-Management of Buddhist Communities in Three Southern Border of Thailand in Violent Situations" under the Higher Education Research Promotion and National Research University Project of Thailand, Office of the Higher Education Commission, Ministry of Education, Thailand.

\section{References}

Bangkok Post. (2013). Militant killed in Yala shootout. Retrieved April 16, 2014, from http://www.bangkokpost.com/breakingnews/281994/militant-slain-in-yala-shooting/

Globalpost. (2012). Thailand: Deadly bomb attacks hit southern province of Yala. Retrieved May 1, 2014, from http://www.globalpost.com/dispatch/news/regions/asia-pacific/thailand/120331/deadly-bomb-attacks-thai-p rovince-yala

Isra News Agencies. (2011). Thailand: Buddhist minority declines the 'deep south' due to protracted armed conflict. Retrieved April 16, 2014, from http://www.isranews.org/south-news/academic-arena/item/4386

Nakata, T. (2010). Terrorism in the Three Southern Border Provinces: Its Major Causes. Songklanakarin Journal of Social Sciences \& Humanities, 16(6), 911-932.

Narongraksakhet, I., Wae-u-seng, N., Yeesunsong, A., Sa-ah, K., Dae-reh, S., Langputeh, S., Laeheem, K., Bilraman, M., Madman, P., Osman, T. \& Kabae, T. (2006). The needs of people in three southern border Provinces. Songklanakarin Journal of Social Sciences \& Humanities, 12(4), 537-559.

Ratjaroenkhajorn, S. (2006). Violence situation in Thailand's three southern border provinces. Retrieved April 16, 2014, from http://www.fpps.or.th/news.php?detail=n1149480173.news

Sakolnakorn, T. P. N. (2013). Violence effecte in the three southern most provinces to local convenience stores. Research Community, 19(112), 25-26.

Sakolnakorn, T. P. N., \& Tepsing, P. (2013). The problems and management strategy of local convenience stores for business survival in violent situations in lower-south Thailand. Asian Social Science, 9(11), 300-307. http://dx.doi.org/10.5539/ass.v9n11p300

Sakolnakorn, T. P. N., Sungkharat, U., \& Tepsing, P. (2013). Problems anda of convenience store entrepreneurs in Tthree Ssouthern border province in Thailand. Nida Development Journal, 53(3), 82-103.

Thai PBS News. (2013). Buddhist community in the three southern border provinces. Retrieved April 16, 2014 from http://news.thaipbs.or.th/

The Economist. (2014). Thailand's violent south: Dreaming of a sultanate: An insurgency worsens as the government promises peace. Retrieved April 16, 2014 from http://www.economist.com/node/21554246

The Nation. (2010). 6 injured in Yala bomb attack. Retrieved April 16, 2014 from http://www.nationmulti media.com/breakingnews/

Winn, P. (2012). Thailand's red zones: who controls them. Retrieved April 16, 2014 from http://www.globalpost.com/dispatches/globalpost-blogs/southeast-asia/thailands-red-zones-army-chief-cont ends-no-area-controlle

Yongyuan, B., Day-ma, C., \& Hiransai, I. (2010). A survey of respect for cultural diversity among teachers in three southern border provinces, Thailand. Songklanakarin Journal of Social Sciences \& Humanities, 16(5), 
$741-758$.

Yongyuan, B., \& Padungpong, C. (2010). Using art activities to promote respect for cultural diversity of elementary school students, Pattani province. Songklanakarin Journal of Social Sciences \& Humanities, 16(6), 953-972.

Deep South Watch. (2013). Buddhist attitude. Retrieved October 20, 2013, from http://www.deepsouthwatch. org/node/4068

\section{Copyrights}

Copyright for this article is retained by the author(s), with first publication rights granted to the journal.

This is an open-access article distributed under the terms and conditions of the Creative Commons Attribution license (http://creativecommons.org/licenses/by/3.0/). 